\title{
Bibliometric Analysis And Visualization Of Funding Social Housing: Connection Of Sociological And Economic Research
}

https://doi.org/10.21272/sec.5(1).144-153.2021.

Svitlana Ianchuk, ORCID ID: https://orcid.org/0000-0002-0657-3040

Postgraduate Student, Sumy State University; Financial Director, 'Global-Trade-S’ LLC, Ukraine

\begin{abstract}
This paper deals with bibliometric analysis and visualization of theory development of funding social housing considering connection of sociological and economic research. The main purpose of the research is to identify dominant trends in cross-sectoral research related to the development of the theory of funding social housing considering connection of sociological and economic research. Systematization literary sources and approaches for solving the problem of funding social housing indicates that the bibliometric analysis of scientific papers indexed in the Scopus database based on using VOSViewer software package and the Scopus scientometric database analysis were not applied enough in the scientific area of this research. Investigation of the topic about research activity in funding social, affordable, and public housing emphasizing the connection of sociological and economic patterns is carried out in the following logical sequence: introduction and proving the relevance of research problem; literature revue with generalization and analysis of scholars experience of bibliometric analysis and visualization in general and in funding social, public, and affordable housing in particular; the main part of investigation related directly to the Scopus scientometric database analysis and the bibliometric analysis of scientific papers indexed in the Scopus database based on using VOSViewer; conclusion of research. Methodological tools of the research methods were logical generalization and scientific abstraction, statistical and structural analysis, comparative, and graphical analysis using Excel 2010 software, Scopus database tools and VOSViewer software package v.1.6.16. The object of the Scopus database analysis was a sample of 5385 scientific articles indexed in the Scopus scientometric database for the period from 1948 to 2020, and generated by the following keywords for search request: 'funding social housing', 'financing social housing', 'social housing finance', 'funding affordable housing', 'financing affordable housing', 'affordable housing finance', 'funding public housing', 'financing public housing', and 'public housing finance' (limit in 2020 is due to the availability of information on open portal of Scopus database and incomplete data for 2021). The top trends of theory development of funding social, affordable, and public housing were identified. The Scopus scientometric database analysis showed that the theory of funding social, affordable, and public housing is at the stage of formation and rapid development - about 60-70\% of the total number of publications for the period from 1948 to 2020 (for more than 70 years) were published in the last 10 years (and about 30-40\% - in the last 5 years). The total trend of number of articles dynamics about funding social, affordable, and public housing indexed in Scopus database in 1990-2020 was built. The accent was put on some significant increase peaks of publishing activity during investigated period connected with the economic and financial crisis in 2007, currency fluctuations, the COVID19 crisis, etc. The structural and functional clustering of the development of the theory of funding social housing was carried out considering connection of sociological and economic research. The received conclusions can be useful for scholars in socioeconomics, public and private investors in social and affordable housing.
\end{abstract}

Keywords: affordable housing, finance, funding, housing allowances, inclusive economy, public and private investment, public housing, social housing, social rental dwellings, subsidies.

JEL Classification: A13, O18, R21. 
SocioEconomic Challenges, Volume 5, Issue 1, 2021

ISSN (print) - 2520-6621, ISSN (online) - 2520-6214

Cite as: Svitlana Ianchuk (2021). Bibliometric Analysis And Visualization Of Funding Social Housing: Connection Of Sociological And Economic Research. SocioEconomic Challenges, 5(1), 144-153. https://doi.org/10.21272/sec.5(1).144-153.2021.

Received: 26.11 .2020

Accepted: 25.02 .2021

Published: 30.03 .2021

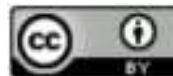

Copyright: (C) 2021 by the author. Licensee Sumy State University, Ukraine. This article is an open access article distributed under the terms and conditions of the Creative Commons Attribution (CC BY) license (https:// creativecommons.org/licenses/by/4.0/).

\section{Introduction}

The unstable socio-economic and political-legal situation in many countries of the world leads to an increase in housing prices and, accordingly, the need for social housing for many segments of the population. Since the global financial crisis of 2008, increasing numbers of low- and middle-income households have been struggling to afford housing (The OECD Housing Project). Before the COVID-19 crisis, house prices had been increasing dramatically in a lot of countries, mostly for renters, and the supply of affordable housing has failed to meet demand. And the COVID-19 pandemic exposed longstanding housing affordability and quality gaps, prompting a range of temporary support measures (OECD, Social housing, 2020). However, social housing is essential not only for many people's well-being, but for sustainable and inclusive economy in general (OECD, Housing and Inclusive Growth, 2020).

Due to the lack of effectiveness of government policy and local programs for funding social housing, the relevance of further research in this area is growing. This issue is urgent both among government officials, private investors, landlords, and in academia. That is why the issue of bibliometric analysis and visualization of funding social housing arouse considerable interest. The main purpose of the research is to identify dominant trends in crosssectoral research related to the development of the theory of funding social housing considering connection of sociological and economic research.

\section{Literature Review}

The problem of social housing is not new in contemporary science. The first and foremost, financial aspects were the subject of attention of many scholars. However, systematization literary sources and approaches for solving the problem of funding social housing indicates that the bibliometric analysis of scientific papers indexed in the Scopus database based on using VOSViewer software package and the Scopus scientometric database analysis were not applied enough in the scientific area of this research.

Nazir et al. (2020) presented a comparison of modular and traditional UK housing construction based on bibliometric analysis. Also, we can find a 10-year bibliometric-based review of real estate rental market (Liu et al., 2020). There are attempts to determine dominant trends in cross-sectorial research related to the theory of financing innovation and the development of the main tools for the implementation of the financial policy of innovation development providing due to bibliometric analysis using VOSViewer software (Samoilikova, 2020), to structure the scientific sphere in social bonds as an instrument of responsible investing based on built-in tools for analyzing the publication of the Scopus database, software VOSviewer 1.6.15 etc. (Yelnikova \& Golochalova, 2020), to analyze the tendency in the scientific literature on the shadow economy which has a negative effect on households' well-being with the tools of VOSviewer, Scopus and Web of Science (Zolkover \& Terziev, 2020).

Bibliometric and trend analysis of public policy, in particular budget transparency was made by Molotok (2020). Kiss (2020) studied the importance of business partnership and presented the results of the bibliometric analysis of the relationship of business partnerships with other categories. Kondratenko et al. (2020) analyzed the impact of public administration on the innovation development and identified the main scientific directions of analysis among the scientific community by the bibliometric study. They allocated 10 clusters of scientific directions which analyzed the issues of innovations and public administrations.

All of the above makes this study relevant and timely. 


\section{Methodology and research methods}

Methodological tools of the research methods were logical generalization and scientific abstraction, statistical and structural analysis, comparative, and graphical analysis using Excel 2010 software, Scopus database tools and VOSViewer software package v.1.6.16.

The object of the Scopus database analysis was a sample of 5385 scientific articles indexed in the Scopus scientometric database for the period from 1948 to 2020, and generated by the following keywords for search request: 'funding social housing', 'financing social housing', 'social housing finance', 'funding affordable housing', 'financing affordable housing', 'affordable housing finance', 'funding public housing', 'financing public housing', and 'public housing finance' (limit in 2020 is due to the availability of information on open portal of Scopus database and incomplete data for 2021). The top trends of theory development of funding social, affordable, and public housing were identified.

We performed a bibliometric analysis of scientific papers published for more than seventy years in issues indexed by the Scopus scientometric database using the VOSViewer software package v.1.6.16 (Van Eck \& Waltman, 2020, 2010; Ranjbar-Sahraei \& Negenborn, 2017). The structural and functional clustering of the development of the theory of funding social housing was carried out considering connection of sociological and economic research.

\section{Results}

Due to the Scopus database analysis, we generated a sample of 5385 scientific articles indexed in the Scopus scientometric database for the period from 1948 to 2020, considering title, abstract, and key words, and operator 'and' by the following keywords for search request: 'funding social housing', 'financing social housing', 'social housing finance', 'funding affordable housing', 'financing affordable housing', 'affordable housing finance', 'funding public housing', 'financing public housing', and 'public housing finance'. Limit in 2020 is due to the availability of information on open portal of Scopus database and incomplete data for 2021.

Results of the Scopus database analysis are shown in Table 1.

Table 1. Results of the Scopus database analysis in the context of funding social housing

\begin{tabular}{|l|c|c|c|c|c|c|}
\hline $\begin{array}{c}\text { Key words for search } \\
\text { request }\end{array}$ & $\begin{array}{c}\text { Total } \\
\text { number of } \\
\text { indexed } \\
\text { articles }\end{array}$ & Time period & $\begin{array}{c}\text { Share of } \\
\text { articles } \\
\text { published } \\
\text { before } 1990 \text { in } \\
\text { total number, } \\
\%\end{array}$ & $\begin{array}{c}\text { Share of } \\
\text { articles } \\
\text { indexed before } \\
2000 \text { in total } \\
\text { number, } \%\end{array}$ & $\begin{array}{c}\text { Share of } \\
\text { articles } \\
\text { indexed after } \\
2010 \text { in total } \\
\text { number, } \%\end{array}$ & $\begin{array}{c}\text { Share of } \\
\text { articles } \\
\text { indexed after } \\
2015 \text { in total } \\
\text { number, } \%\end{array}$ \\
\hline funding social housing & 774 & $1973-2020$ & 5,04 & 11,89 & 66,28 & 38,11 \\
\hline financing social housing & 611 & $1966-2020$ & 14,40 & 28,48 & 51,06 & 29,46 \\
\hline social housing finance & 976 & $1950-2020$ & 7,99 & 21,82 & 59,12 & 36,48 \\
\hline funding affordable housing & 231 & $1988-2020$ & 0,87 & 6,49 & 72,73 & 38,10 \\
\hline financing affordable housing & 215 & $1984-2020$ & 1,86 & 11,63 & 67,91 & 37,67 \\
\hline affordable housing finance & 315 & $1982-2020$ & 0,95 & 8,89 & 72,70 & 41,59 \\
\hline funding public housing & 748 & $1973-2020$ & 5,88 & 15,51 & 60,43 & 30,61 \\
\hline financing public housing & 637 & $1964-2020$ & 13,66 & 28,73 & 51,18 & 26,84 \\
\hline public housing finance & 878 & $1948-2020$ & 10,48 & 21,87 & 56,72 & 29,27 \\
\hline
\end{tabular}

Source: developed by the author based on Scopus database tools.

Scientific papers about funding social, affordable, and public housing were published for more than 70 years in issues indexed by the Scopus scientometric database. The first publication on this topic is dated by 1948. However, most scientific articles from the sample were published and indexed in the last 5-10 years (Table 1, Figure 1). The analysis showed that the theory of funding social, affordable, and public housing is at the stage of formation and rapid development - about 60-70 \% of the total number of publications for the period from 1948 to 2020 were published in the last 10 years (and about 30-40 \% - in the last 5 years). We also studied the dynamics of publishing activity on the issue of financing social, affordable, and public housing (Figures 2-4). The dynamic 
analysis of number of articles about funding social housing indexed in Scopus database in 1990-2020 is shown in Figure 2. Generally, there is similar dynamics of development of publishing activity for all analyzed key search requests, but there is different number of publications. In our opinion, the concept of 'funding social housing' is more common than 'financing social housing'. What is more, there are a lot of increase and decrease peaks during investigated time. For example, we can see a long rise of research interest to funding social housing from 2008 to 2012. It is explained by economic and financial crisis in 2007 and its consequences for people financial status and their housing needs. The increase of popularity of social housing from 2015 to 2018 relates to currency fluctuations in many countries around the world and the devaluation of the national currency, which leads to lower incomes, higher housing prices and increased needs for social and affordable housing.

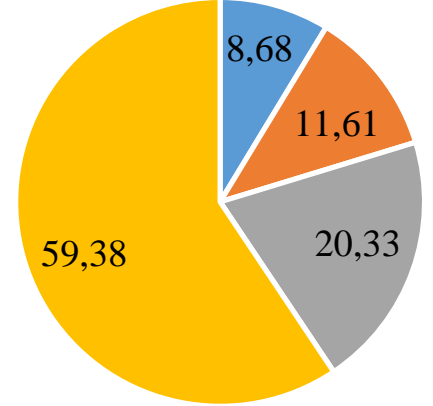

- share of articles indexed before 1990 in total number, \%

- share of articles indexed from 1990 to 2000 total number, \%

- share of articles indexed from 2000 to 2010 total number, $\%$

- share of articles published after 2010 in total number, $\%$

a) funding social housing

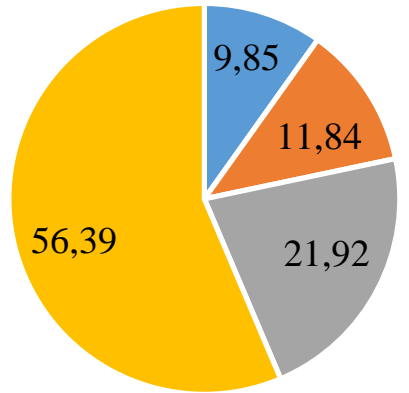

- share of articles indexed before 1990 in total number, $\%$

- share of articles indexed from 1990 to 2000 total number, $\%$

- share of articles indexed from 2000 to 2010 total number, $\%$

- share of articles published after 2010 in total number, $\%$

\section{c) funding public housing}

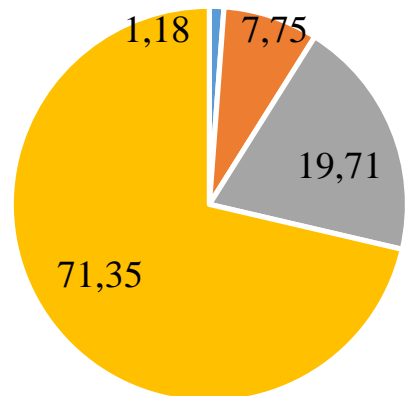

- share of articles indexed before 1990 in total number, $\%$

- share of articles indexed from 1990 to 2000 total number, $\%$

- share of articles indexed from 2000 to 2010 total number, \%

- share of articles published after 2010 in total number, $\%$

\section{b) funding affordable housing}

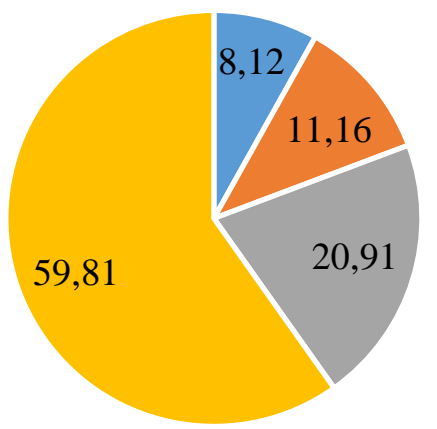

- share of articles indexed before 1990 in total number, $\%$

- share of articles indexed from 1990 to 2000 total number, $\%$

- share of articles indexed from 2000 to 2010 total number, $\%$

- share of articles published after 2010 in total number, $\%$

\section{d) funding social, affordable, and public housing in general}

Figure 1. Structural analysis of publishing activity on the topic of funding social, affordable, and public housing in scientific journals indexed in Scopus database in 1948-2020

Source: developed by the author based on Scopus database tools and Excel software. 


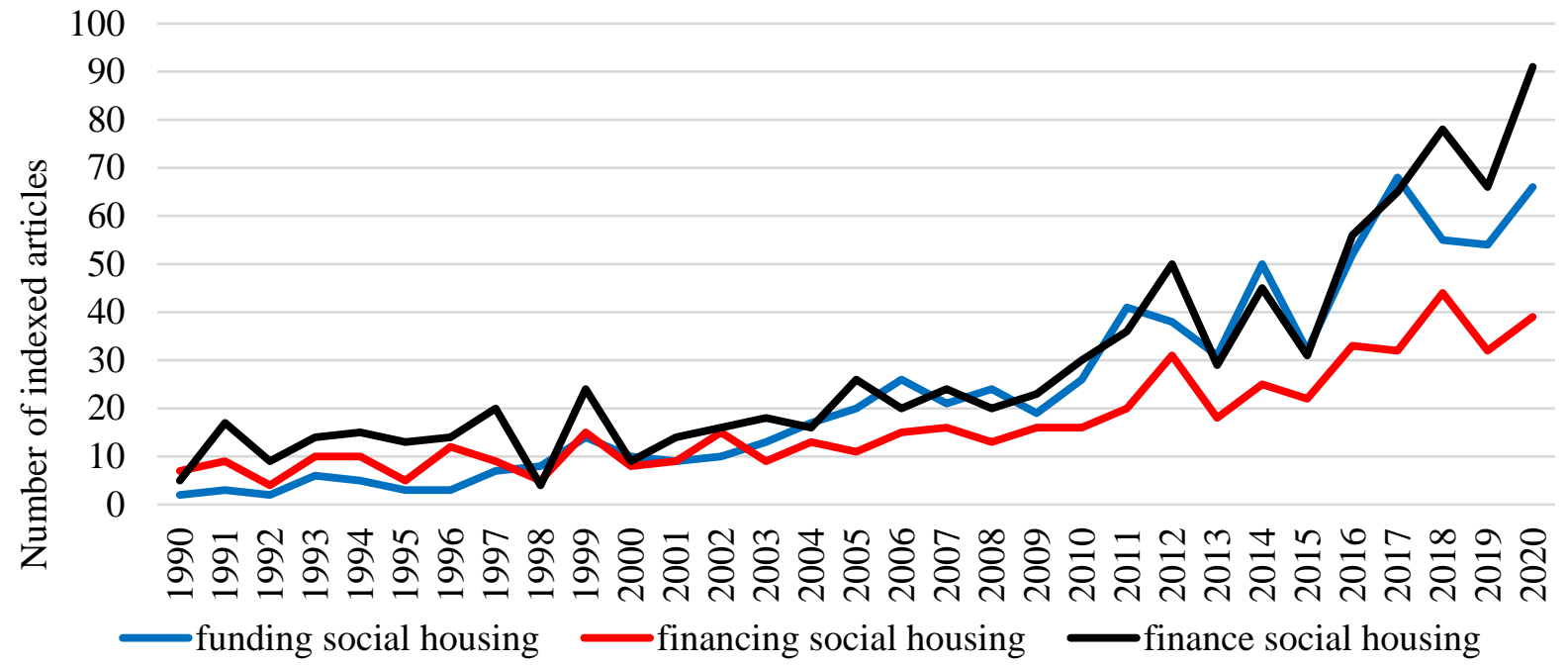

Figure 2. The dynamic analysis of number of articles about funding social housing indexed in Scopus database in 1990-2020

Source: developed by the author based on Scopus database tools and Excel software.

Moreover, before the COVID-19 crisis (the end of 2019), house prices had been increasing dramatically in a lot of countries, mostly for renters, and the supply of affordable housing has failed to meet demand. Obviously, the COVID-19 pandemic exposed longstanding housing affordability and quality gaps, promoting a range of temporary support measures (OECD, 2020).

The dynamic analysis of number of articles about funding affordable housing indexed in Scopus database in 19902020 is shown in Figure 3.

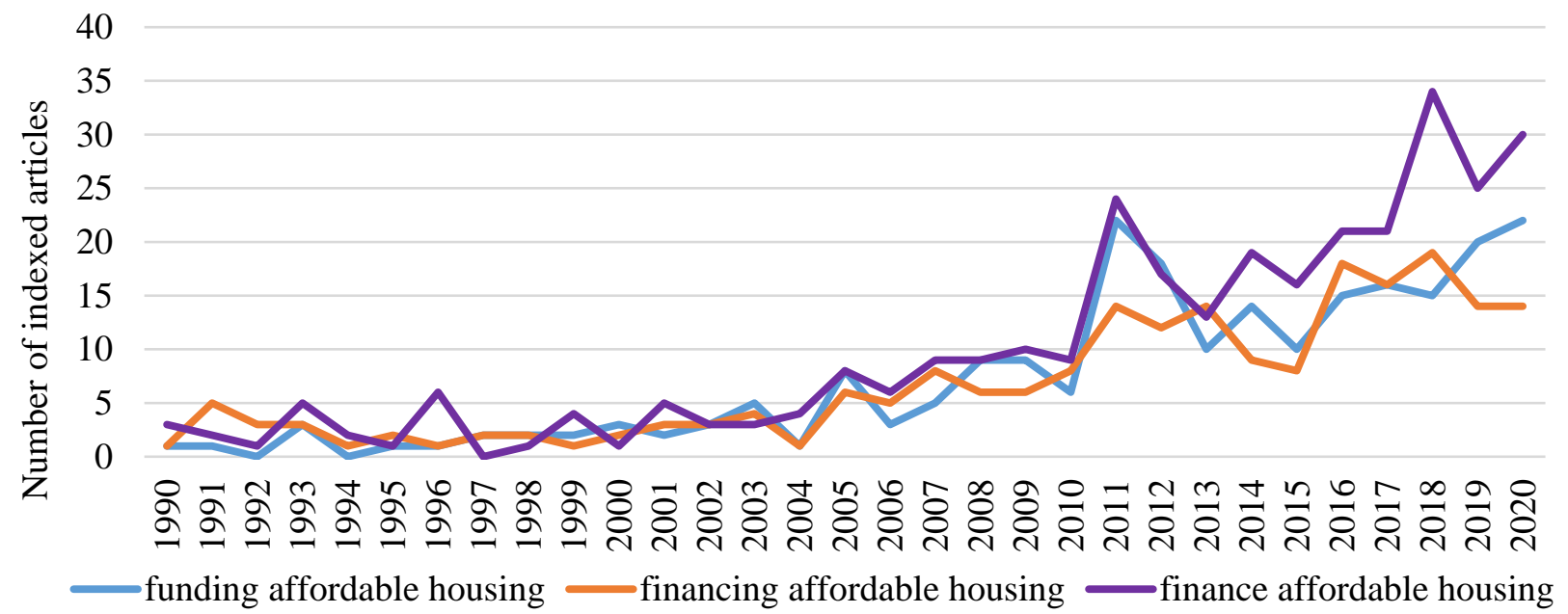

Figure 3. The dynamic analysis of number of articles about funding affordable housing indexed in Scopus database in 1990-2020

Source: developed by the author based on Scopus database tools and Excel software.

The general tendency of research interest and publishing in Scopus is positive in the context of all key search requests such as 'funding affordable housing', 'financing affordable housing', and 'affordable housing finance'. The total trend and dynamics peculiarities are similar the previous research step. However, there are more changeable peaks. 
The dynamic analysis of number of articles about funding public housing indexed in Scopus database in 19902020 is shown in Figure 4.

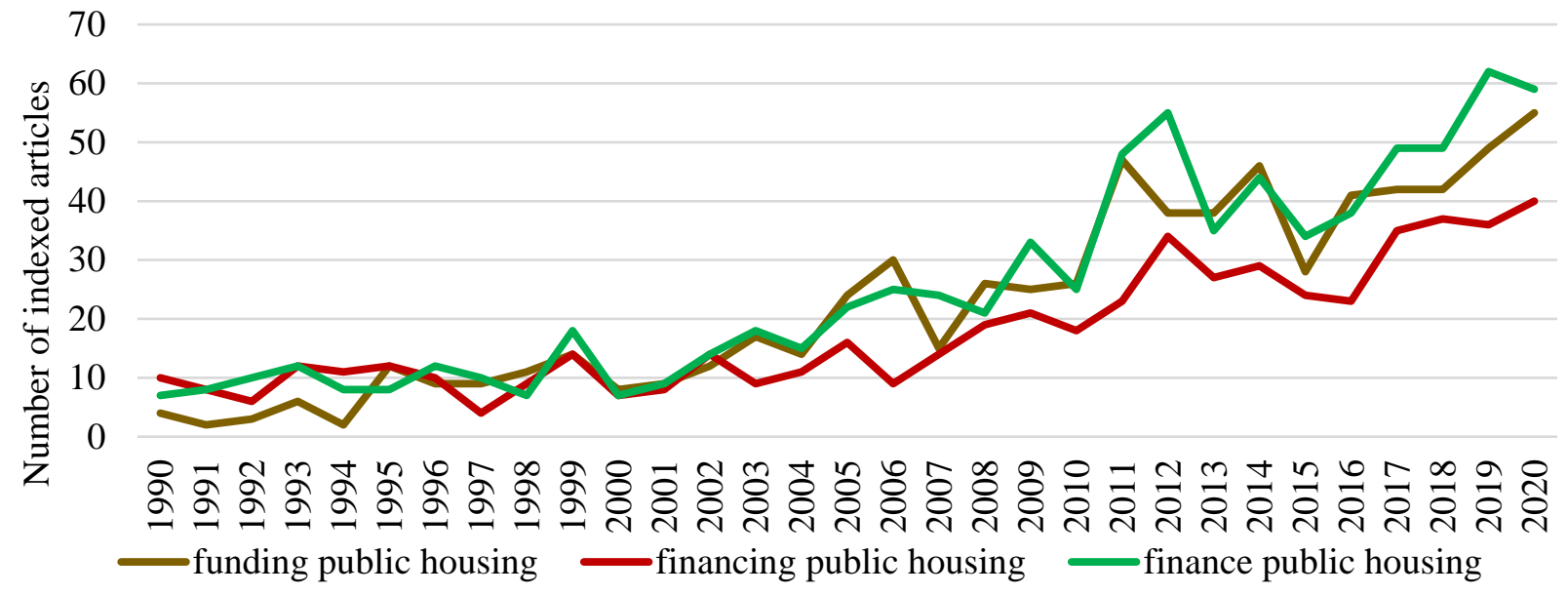

\section{Figure 4. The dynamic analysis of number of articles about funding public housing indexed in Scopus database in 1990-2020}

Source: developed by the author based on Scopus database tools and Excel software.

In this case we can say about more popularity of the concept of 'funding public housing' in comparison with 'financing public housing' too. The general tendency of research interest and publishing in Scopus is positive in the context of all key search requests such as 'funding public housing', 'financing public housing', and 'public housing finance'. Also, there are a lot of increase and decrease peaks during investigated time. The dominant reasons are the same as in case of funding social housing (economic and financial crisis, currency fluctuations, and the COVID-19 pandemic consequences).

To sum up, the trend analysis of number of articles dynamics about funding social, affordable, and public housing indexed in Scopus database in 1990-2020 is shown in Figure 5.

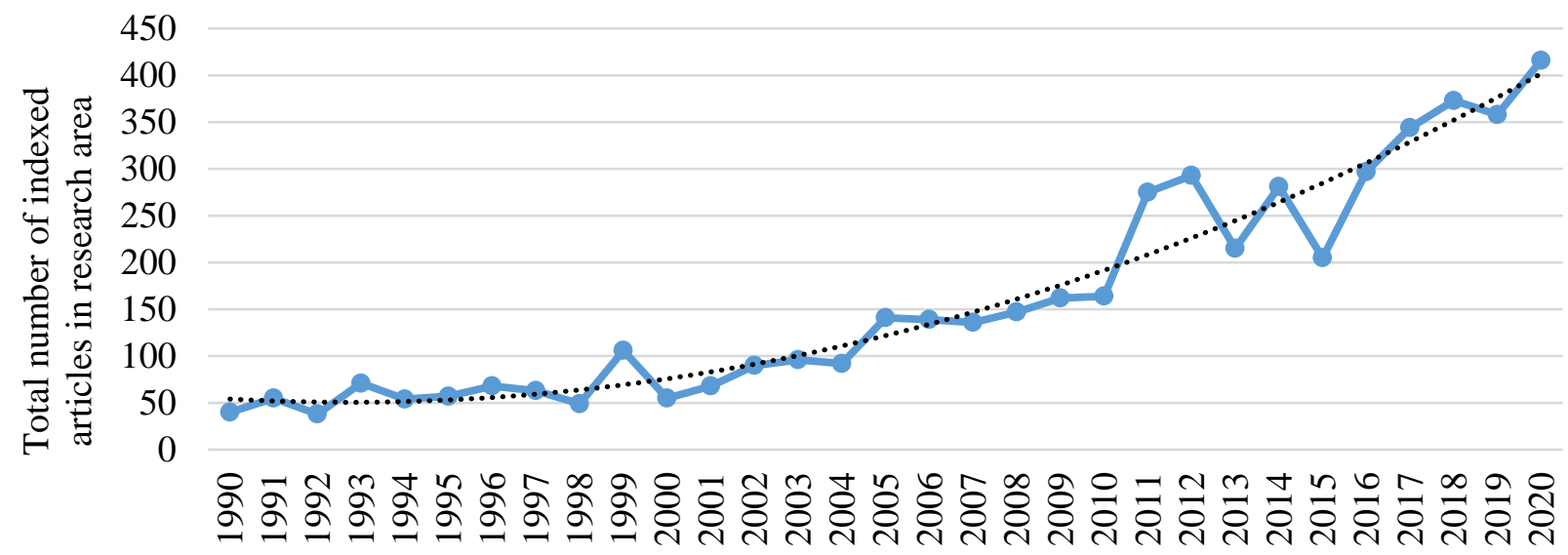

Figure 5. The trend analysis of number of articles dynamics about funding social, affordable, and public housing indexed in Scopus database in 1990-2020

Source: developed by the author based on Scopus database tools and Excel software.

We can argue about significant positive development of this research area based on the Scopus scientometric database analysis. 
The next step of our research is a bibliometric analysis of scientific papers about funding social housing indexed in the Scopus database for 70 years, based on using VOSViewer v.1.6.16.

For bibliometric analysis of research about funding social housing, a sample of 2361 scientific articles was formed, which used the key phrases 'funding social housing', 'financing social housing', and 'social housing finance'. 352 keywords were selected from 8445, the frequency of use of which is a multiple of 15 or more (Figure 6).

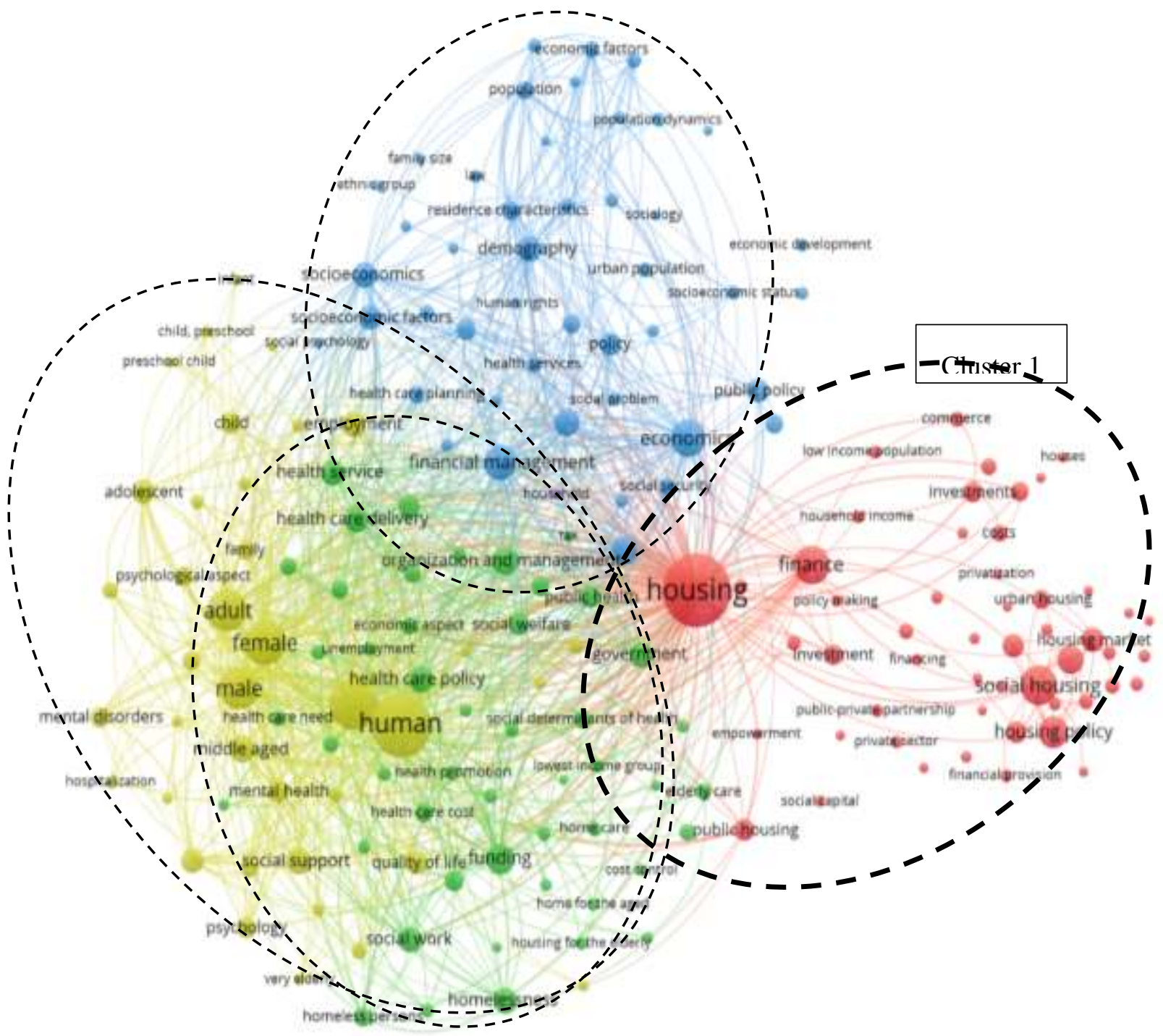

Figure 6. Dominant clusters of cross-sectoral research of funding social housing

Source: developed by the author based on VOSViewer software v.1.6.16

Conducting a bibliometric analysis made it possible to identify 4 clusters, which show the issue of funding social housing is most often studied in close connection with theories:

1. housing finance (household income, investment, public-private partnership, privatization, social housing, public housing);

2. socioeconomics (economics, sociology, financial government, financial management, social police, socioeconomic status, social problems, demography); 
3. human's behavior (gender, age, phycology, health status, social support, health care, quality of life);

4. funding social work (organization and management, cost control, health promotion, health service, unemployment, homelessness) (clusters 1-4, Figure 6).

Also, we chose 50 countries with minimum 5 documents of a country from 136 countries represented in the investigated sample of 2361 scientific articles. An attention was paid on the countries with the largest number of publications on this issue (Table 2).

Table 2. Top-20 countries by research activity in funding social housing based on Scopus database analysis

\begin{tabular}{|c|l|c|c|l|l|c|c|}
\hline № & \multicolumn{1}{|c|}{ Country } & Documents & Citations & № & \multicolumn{1}{c|}{ Country } & Documents & Citations \\
\hline 1 & USA & 556 & 7400 & 11 & Russian Federation & 37 & 107 \\
\hline 2 & United Kingdom & 419 & 9142 & 12 & Sweden & 34 & 660 \\
\hline 3 & Australia & 161 & 1518 & 13 & Spain & 33 & 279 \\
\hline 4 & Canada & 107 & 1659 & 14 & Ireland & 29 & 307 \\
\hline 5 & Netherlands & 80 & 993 & 15 & Brazil & 27 & 226 \\
\hline 6 & Germany & 53 & 380 & 16 & New Zealand & 23 & 309 \\
\hline 7 & China & 51 & 420 & 17 & Hong Kong & 22 & 477 \\
\hline 8 & France & 42 & 231 & 18 & Singapore & 19 & 278 \\
\hline 9 & South Africa & 39 & 363 & 19 & India & 19 & 164 \\
\hline 10 & Italy & 39 & 326 & 20 & Malaysia & 18 & 143 \\
\hline
\end{tabular}

Source: developed by the author based on VOSViewer software v.1.6.16.

Table 2 shows the results of the ranking of the 20 leading countries in the number of scientific publications and their citations. It should be noted that in Denmark, Finland, Belgium, and Mexico the number of publications is smaller, but the number of citations is significant - on the level of leading countries.

The dominant organizations with affiliation in the Scopus database and a maximum publication in this research context include University of New South Wales, Swinburne University of Technology, RMIT University, Curtin University, University of Sydney, University of Tasmania, University of Western Australia, and University of Queensland (Australia), University of Glasgow, London School of Economics, and University of Sheffield (United Kingdom), Massachusetts Institute of Technology and Johns' Hopkins University (United States), University of Toronto (Canada), Center for development support of University of the Free State (Bloemfontein, South Africa), Department of Mental Health and Substance Abuse (World Health Organization, Geneva, Switzerland), and National University of Singapore (Singapore).

\section{Conclusions}

The Scopus scientometric database analysis showed that the theory of funding social, affordable, and public housing is at the stage of formation and rapid development - about 60-70\% of the total number of publications for the period from 1948 to 2020 (for more than 70 years) were published in the last 10 years (and about 30-40 $\%$ - in the last 5 years). We identified the similar positive dynamic of development of publishing activity for all analyzed key search requests in the context of funding social, affordable, and public housing, but there is different number of publications, and increase, and decrease peaks. More attention is paid to social, and public housing compared with affordable one. The concept of 'funding social housing' is more common than 'financing social housing'. The total trend of number of articles dynamics about funding social, affordable, and public housing indexed in Scopus database in 1990-2020 was built. It is growing and positive.

The accent was put on some significant increase peaks of publishing activity during investigated time period: 1) a long rise of research interest to funding social housing from 2008 to 2012 what is explained by economic and financial crisis in 2007 and its consequences for people financial status and their housing needs; 2) the increase of popularity of social housing from 2015 to 2018 related to currency fluctuations in many countries around the world and the devaluation of the national currency, which leads to lower incomes, higher housing prices and increased needs for social and affordable housing; 3) a current rise connected with the COVID-19 crisis (from the end of 2019) and its negative consequences, mostly for renters. 
We determine dominant trends in cross-sectoral research related to the important issue of funding social housing due to the bibliometric analysis of scientific papers indexed in the Scopus database based on using VOSViewer v.1.6.16. We identified 4 clusters, which show the issue of funding social housing is most often studied in close connection with theories: 1) housing finance (household income, investment, public-private partnership, privatization, social housing, public housing); 2) socioeconomics (economics, sociology, financial government, financial management, social police, socioeconomic status, social problems, demography); 3) human's behavior (gender, age, phycology, health status, social support, health care, quality of life); 4) funding social work (organization and management, cost control, health promotion, health service, unemployment, homelessness). Top countries and organizations in research activity related to funding social housing based on Scopus database analysis were also determined. Thus, the structural and functional clustering of the development of the theory of funding social housing was carried out considering connection of sociological and economic research.

Funding. Self-funded.

Author Contributions: conceptualization, Svitlana Ianchuk; methodology, Svitlana Ianchuk; validation, Svitlana Ianchuk; formal analysis, Svitlana Ianchuk; investigation, Svitlana Ianchuk; resources, Svitlana Ianchuk; data curation, Svitlana Ianchuk; writing original draft preparation, Svitlana Ianchuk; writing review and editing, Svitlana Ianchuk; visualization, Svitlana Ianchuk; supervision, Svitlana Ianchuk; project administration, Svitlana Ianchuk.

\section{References}

1. Kiss, L. B. (2020). The Importance of Business Partnership on the World Wide Web. Business Ethics and Leadership, 4(1), 68-79. DOI: http://doi.org/10.21272/bel.4(1).68-79.2020.

2. Kondratenko, V., Okopnyk, O., Ziganto, L., \& Kwilinski, A. (2020). Innovation Development of Public Administration: Management and Legislation Features. Marketing and Management of Innovations, 1, 8794. DOI: https://doi.org/10.21272/mmi.2020.1-06.

3. Liu, Y., Wang, P., He, Z., \& Dong, J. (2020). Real estate rental market: a 10-year bibliometric-based review. Economic Research-Ekonomska Istraživanja. Published Online. DOI: https://doi.org/10.1080/1331677X.2020.1848605.

4. Molotok, I. F. (2020). Bibliometric and Trend Analysis of Budget Transparency. Business Ethics and Leadership, 4(2), 116-122. DOI: https://doi.org/10.21272/bel.4(2).116-122.2020.

5. Nazir, F. A., Edwards, D. J., Shelbourn, M., Martek, I., Thwala, W. D. D., \& El-Gohary, H. (2020). Comparison of modular and traditional UK housing construction: a bibliometric analysis. Journal of Engineering, Design and Technology, 19(1), 164-186. DOI: https://doi.org/10.1108/JEDT-05-2020-0193.

6. OECD (2020). Housing and Inclusive Growth. OECD Publishing, Paris. DOI: https://doi.org/10.1787/6ef36f4b-en.

7. OECD (2020). Social housing: A key part of past and future housing policy. Employment, Labour and Social Affairs Policy Briefs. OECD, Paris. Available at: http://oe.cd/social-housing-2020.

8. OECD Housing Project. (n.d.). Affordable housing. Available at: http://www.oecd.org/housing/topics/affordable-housing/.

9. Ranjbar-Sahraei, B., \& Negenborn R. R. (2017). Research Positioning \& Trend Identification - a dataanalytics toolbox. AIDA project. Available at: https://d1rkab7tlqy5f1.cloudfront.net/Library/Themaportalen/Research\%20Analytics/AIDA-Booklet.pdf.

10. Samoilikova, A. V. (2020). Finansova polityka zabezpechennya innovatsiynoho rozvytku Ukrayiny [Financial policy of providing the innovation development of Ukraine]. The dissertation for obtaining a candidate degree in Economics in specialty 08.00.08 Money, Finance and Credit. Sumy State University, Sumy. [in Ukrainian]. Available at: https://essuir.sumdu.edu.ua/bitstreamdownload/123456789/80856/1/diss_Samoilikova.pdf.

11. Scopus (n.d.). Scopus database tools. Start exploring. Available at: https://www.scopus.com/search/form.uri?zone=TopNavBar\&origin=searchbasic\&display=basic\#basic.

12. Van Eck, N. J., \& Waltman, L. (2010). Software survey: VOSviewer, a computer program for bibliometric mapping. Scientometrics, 84(2), 523-538. DOI: https://doi.org/10.1007/s11192-009-0146-3. 
13. Van Eck, N. J., \& Waltman, L. (2020). VOSviewer Manual. Available at: https://www.vosviewer.com/getting-started\#vosviewer-manual.

14. Yelnikova, Y., \& Golochalova, I. (2020). Social Bonds as an Instrument of Responsible Investment. Financial Markets, Institutions and Risks, 4(4), 119-128. https://doi.org/10.21272/fmir.4(4).119-128.2020.

15. Zolkover, A., \& Terziev, V. (2020). The Shadow Economy: A Bibliometric Analysis. Business Ethics and Leadership, 4(3), 107-118. DOI: https://doi.org/10.21272/bel.4(3).107-118.2020. 